\title{
Foliar Applied Calcium Improves Seed Yield and Yield Components of Alfalfa
}

\author{
Hui Wang ${ }^{1 \dagger}$, Wenxu Zhang ${ }^{2, \dagger}$, Xiaoxing Wei ${ }^{3}$, Yan Sun ${ }^{1}$, Mingya Wang ${ }^{1}$ and Peisheng Mao ${ }^{{ }^{*}}$ \\ ${ }^{1}$ Forage Seed Laboratory, China Agricultural University; Beijing Key Laboratory of Grassland Science, Beijing, PR China \\ ${ }^{2}$ College of Chemistry and Chemical Engineering, Northwest Normal University, Lanzhou 730070, Gansu Province, PR China \\ ${ }^{3}$ Qinghai Academy of Animal and Veterinary Science, Xining 810016, Qinghai Province, PR China
}

*For correspondence: cgssst@sina.com

${ }^{\dagger}$ These authors contributed equally to this work

\begin{abstract}
A field experiment was carried out during 2009 to 2012 . Calcium chloride $\left(\mathrm{CaCl}_{2}\right)$ at five levels $\left(0,0.2,0.4,0.6,0.8 \mathrm{mg} \mathrm{g}^{-1}\right)$ was applied as foliar sprays at the initial and peak flowering of alfalfa (Medicago sativa L.) and data were recorded for seed yield and yield components. Results showed that the year, calcium $(\mathrm{Ca})$ levels and the interaction affected significantly seed yield and yield components except seeds per pod. The highest seed yield was obtained in $2012\left(746.82 \mathrm{~kg} \mathrm{ha}^{-1}\right)$ and lowest in $2010\left(116.08 \mathrm{~kg} \mathrm{ha}^{-1}\right)$. With the Ca levels increasing from 0.2 to $0.8 \mathrm{mg} \mathrm{g}^{-1}$, the highest seed yield $\left(585.41 \mathrm{~kg} \mathrm{ha}^{-1}\right)$ was obtained for the $0.4 \mathrm{mg} \mathrm{g}^{-1}$ treatment. Additionally, flowers per raceme $\left(\mathrm{r}=0.56^{* *}\right)$ and pods per raceme ( $\left.\mathrm{r}=0.61^{* *}\right)$ was significantly and positively correlated with alfalfa seed yield, respectively. Path analysis depicted that pods per raceme influenced positively and directly seed yield $\left(\mathrm{pc}=0.60^{* *}\right)$ and flowers per raceme had a positively indirect effect via pods per raceme on seed yield $\left(\mathrm{pc}=0.40^{* *}\right)$. Racemes per square meter negatively and directly affected seed yield ( $\mathrm{pc}=-0.223$ ), but racemes per square meter had a positively indirect effect via pods per raceme on seed yield ( $\mathrm{pc}=0.23$ ). It could be suggested that $0.4 \mathrm{mg} \mathrm{g}^{-1} \mathrm{Ca}$ level was beneficial for improving alfalfa seed yield and pods per raceme as crucial yield component in alfalfa. (C) 2016 Friends Science Publishers
\end{abstract}

Keywords: Alfalfa; Spraying; Fertilization; Yield; Correlation

\section{Introduction}

For forage crop, seed yield is not part of the agronomic value. However, in alfalfa, the commercial success of a new variety depends not only on its forage production, but also seed attributes (Falcinelli, 1999). However, a large variations is observed in seed yield of alfalfa (Narinov and Kljuj, 1990), due to many factors including genotype, climatic conditions and agronomic management.

Genetics should be taken into consideration to attain high quality seeds (Barnes and Sheaffer, 1995). Genetic diversity of alfalfa for seed yield and yield components has been identified (Bolanos-Aguilar et al., 2000). Nevertheless, breeding for the actual seed yield enhancement has been restricted. Suitable environmental conditions are essential for seed production of alfalfa. In years with excessive precipitation, alfalfa plants tend to prolong the vegetative growth phase and lodge easily. In years with very low temperature, which affects plant growth and reduces insect activity, alfalfa seed yield will be poorly meager. Thus, favorable climate should be low relative humidity and moderate air temperature (Rincker et al., 1988).

Generally, a balanced supply of nutrients is essential for ideal seed yield and seed quality. Calcium $(\mathrm{Ca})$ plays a pivotal role in plant growth, development and respond to external and internal signals (Reddy, 2001; Kudla et al., 2010). Lots of researches on the effect of $\mathrm{Ca}$ in crop plants are reported. For instance, $\mathrm{Xu}$ et al. (2013) reported that $\mathrm{Ca}$ could improve the photosynthetic rate of zoysiagrass (Zoysia japonica Steud.) under drought conditions. Ca deficiency restrains the growth of meristematic tissues and youngest leaves would become deformed and chlorotic (Marschner, 1995). Additionally, Ca supply can promote nitrogen absorption and increase nitrogen use efficiency to make plant active (Mahmood et al., 2009). Ca contributes to the growth and survival of symbiotic bacteria in legume, and could increase the yield of groundnut and soybean (Wang et al., 2004; Gashti et al., 2012). For alfalfa, it has been reported that exogenous $\mathrm{Ca}$ could accelerate the ability of alfalfa seedling to resist cold, drought and salt (You et al., 2003; Jiang et al., 2008; Liu et al., 2011). However, little is known about the efficiency of foliar applied $\mathrm{Ca}$ in improving alfalfa seed yield. Furthermore, a major problem with $\mathrm{Ca}$ nutrition is its low plant and soil mobility. Unlike most other nutrients, $\mathrm{Ca}$ cannot mobilize from older to younger tissues. Thus, the objectives of this 
study were to investigate whether foliar applied $\mathrm{Ca}$ could increase alfalfa seed yield during the consecutive growing year and determine the optimum concentration, in order to provide the information for fertilization management of alfalfa seed production.

\section{Materials and Methods}

\section{Experimental Site}

The experiment was carried out at the Etuoke Banner, Inner Mongolia Autonomous Region, China (latitude, $39^{\circ} 12^{\prime} \mathrm{N}$; longitude, $106^{\circ} 95^{\prime} \mathrm{E}$; elevation, $1150 \mathrm{~m}$ ) from 2009 to 2012. The soil type $(0-30 \mathrm{~cm})$ was gray meadow with $\mathrm{pH}$ of 8.98 ; organic matter, $9.71 \mathrm{~g} \mathrm{~kg}^{-1}$; alkaline-hydrolysable nitrogen, $72.7 \mathrm{mg} \mathrm{kg}^{-1}$; phosphorus, $7.24 \mathrm{mg} \mathrm{kg}^{-1}$; potassium, $74 \mathrm{mg}$ $\mathrm{kg}^{-1}$; and $\mathrm{Ca}, 93 \mathrm{mg} \mathrm{kg}$. Weather data was obtained from local observing station.

\section{Experimental Materials}

The sowing seed of the alfalfa (Medicago sativa L. var. Zhongmu No. 2) was provided by the Institute of Animal Science, Chinese Academy of Agricultural Sciences.

\section{Field Trials Design}

The field trial was established on April 10, 2008 at the seed rate of $10 \mathrm{~kg} \mathrm{ha}^{-1}$. The experimental plot was $36 \mathrm{~m}^{2}(4.5$ $\mathrm{m} \times 8 \mathrm{~m}$ ). Randomized complete blocks were designed with three replicates. The crop was sprayed with $\mathrm{CaCl}_{2}$, at five concentrations $\left(0,0.2,0.4,0.6,0.8 \mathrm{mg} \mathrm{g}^{-1}\right) @ 1000 \mathrm{~L} \mathrm{ha}^{-1}$, at the initial and peak flowering stage respectively. $\mathrm{P}_{2} \mathrm{O}_{5}(750$ $\mathrm{kg} \mathrm{ha}{ }^{-1}$ ) and $\mathrm{K}_{2} \mathrm{O}\left(180 \mathrm{~kg} \mathrm{ha}^{-1}\right)$ were applied as base fertilizers. Irrigation was performed according to the climate conditions during the returning green period.

\section{Methods and Data Collection}

The first year was considered as the establishment year. Measurements for data collection were performed during the subsequent 4 years. During 2009 to 2012, the four yield components recorded were racemes per square meter, flowers per raceme, pods per raceme, and seeds per pod. To measure racemes per square meter at the peak flowering. Thirty racemes and pods each were stochastically selected from each sampling unit to measure the average number of flowers per raceme, pods per raceme, and seeds per pod. Seed yield per unit area was obtained from the weight of seeds of each plot.

\section{Statistical Analysis}

The experiments were conducted for 4 consecutive years (from 2009 to 2012) at the same location. Years, Ca treatments $\left(0,0.2,0.4,0.6\right.$ and $\left.0.8 \mathrm{mg} \mathrm{g}^{-1}\right)$, and their interactions were examined with a standard $F$-test. The data were analyzed statistically using completely randomized block design. Means of each treatment were compared by Fisher's protected LSD test with a significant level of 0.05 . Pearson correlation analysis was analyzed among seed yield and yield components. Pathcoefficient was used for determining relationships among components of alfalfa seed yield. These analysis were performed using SAS (version 8.0).

\section{Results}

\section{Effect of Climate on Seed Yield and Yield Components}

During the four growing years, environmental conditions were quite variable, especially during flowering and pod formation (June and July), due to the change in temperature and rainfall (Table 1). The growing season in 2012 was warm and dry, but in 2010 the spring was quite humid especially in May $(82.0 \mathrm{~mm})$ at flowering and fertilization. Meanwhile, lowest monthly temperature $\left(0.4^{\circ} \mathrm{C}\right)$ and mean monthly temperature $\left(6.3^{\circ} \mathrm{C}\right)$ were lower in April 2010 than other experimental years, which coincident with the beginning of plant reviving. Furthermore, the total sunny hours in May 2010 were fewer than other experimental years resulting in lower products of photosynthesis.

Results of compound variance analysis presented meaningful differences $(P<0.01)$ among experimental years for seed yield components and seed yield (Table 2 ). The climate change was a key factor to affect seed yield components and seed yield among years. Results obtained from 2009 to 2012 indicated meaningful differences $(P<0.05)$ for seed yield among the consecutive years, the highest seed yield of alfalfa was attained in $2012\left(746.82 \mathrm{~kg} \mathrm{ha}^{-1}\right)$ and the lowest in 2010 (116.08 kg ha-1, Table 3). Similarly, flowers per raceme and pods per raceme were significantly $(P<0.05)$ higher in 2012 than other experimental years. Because of more rainfall $(82.0 \mathrm{~mm})$ and less sunny hours $(253.9 \mathrm{~h})$ in May 2010, flowers per raceme and seed yield were both meaningfully $(P<0.05)$ lower than other experimental years.

\section{Effects on Seed Yield Components}

Number of racemes per square meter: A decrease with increase in concentration from 0.2 to $0.8 \mathrm{mg} \mathrm{g}^{-1}$ was observed and higher racemes per square meter significantly $(P<0.05)$ than $\mathrm{CK}\left(0.0 \mathrm{mg} \mathrm{g}^{-1}\right)$ (Table 4$)$. At 0.2 and $0.4 \mathrm{mg} \mathrm{g}^{-1} \mathrm{Ca}$ supply, racemes per square meter were highest with no significant difference $(P>0.05)$ between these two treatments as compared to others. 
Table 1: High, low, mean monthly temperature, sunshine hours and rainfall in 2009-2012

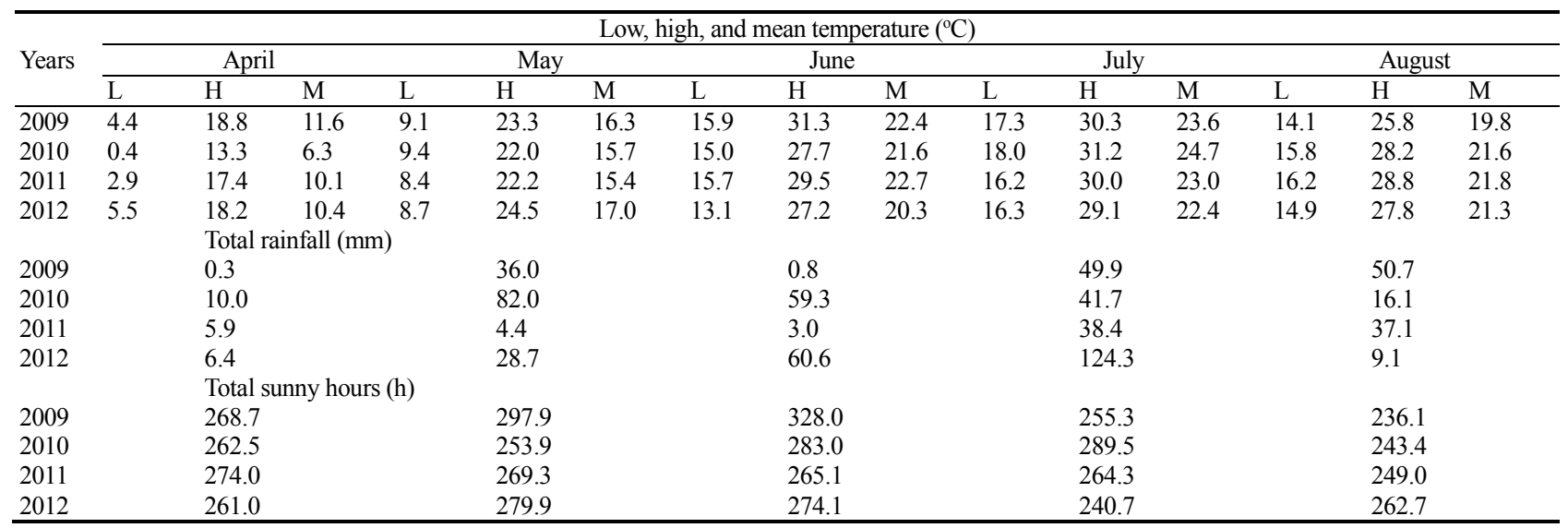

L, lowest monthly temperature; $\mathrm{H}$, highest monthly temperature; $\mathrm{M}$, mean monthly temperature

Table 2: $\mathrm{F}$ tests of year, $\mathrm{Ca}$ and their interactions on seed yield and yield components of alfalfa

\begin{tabular}{|c|c|c|c|c|c|c|}
\hline \multirow[t]{2}{*}{ Source } & \multirow[t]{2}{*}{$\mathrm{df}$} & \multicolumn{5}{|c|}{ Mean square } \\
\hline & & Racemes per square meter & Flowers per raceme & Pods per raceme & Seeds per pod & Seed yield \\
\hline $\mathrm{Ca}$ & 4 & $* *$ & $*$ & $* *$ & NS & $* *$ \\
\hline Year & 3 & $* *$ & $* *$ & $* *$ & $* *$ & $* *$ \\
\hline
\end{tabular}

$* \mathrm{P}<0.05, * * \mathrm{P}<0.01, \mathrm{NS}$, not significant

Table 3: Trend response to seed yield and yield components of alfalfa from 2009 to 2012

\begin{tabular}{|c|c|c|c|c|c|}
\hline Years & Racemes per square meter & Flowers per raceme & Pods per raceme & Seeds per pod & Seed yield $\left(\mathrm{kg} \mathrm{ha}^{-1}\right)$ \\
\hline 2009 & $5429.3 \mathrm{~d}$ & $22.13 \mathrm{~b}$ & $7.86 \mathrm{c}$ & $4.89 \mathrm{~b}$ & $517.74 \mathrm{c}$ \\
\hline 2010 & $12083.0 \mathrm{~b}$ & $19.97 \mathrm{c}$ & $7.93 \mathrm{c}$ & $5.27 \mathrm{a}$ & $116.08 \mathrm{~d}$ \\
\hline 2011 & $13022.7 \mathrm{a}$ & $20.32 \mathrm{c}$ & $8.60 \mathrm{~b}$ & $5.46 \mathrm{a}$ & $578.34 \mathrm{~b}$ \\
\hline 2012 & $11474.0 \mathrm{c}$ & $24.91 \mathrm{a}$ & $10.34 \mathrm{a}$ & $5.33 \mathrm{a}$ & $746.82 \mathrm{a}$ \\
\hline \multicolumn{6}{|c|}{ Means in the same column with different letters are significantly different at the 0.05 level } \\
\hline
\end{tabular}

Table 4: Effect of Ca treatments on seed yield and yield components of alfalfa from 2009 to 2012

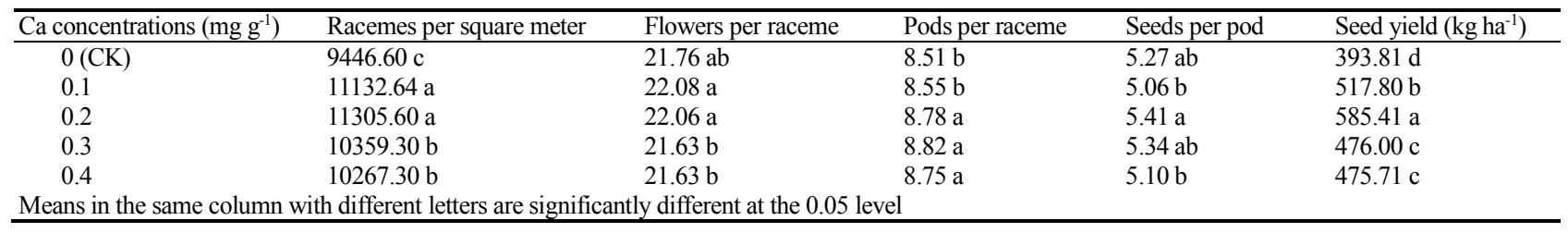

Number of flowers per raceme: Number of flowers per raceme also showed significant $(P<0.05)$ influence of $\mathrm{Ca}$ treatments (Table 2). Flowers per raceme decreased with the increasing $\mathrm{Ca}$ level, but there were no significant differences $(P>0.05)$ between $\mathrm{Ca}$ treatments and CK (Table 4). Flowers per raceme with 0.2 and $0.4 \mathrm{mg} \mathrm{g}^{-1} \mathrm{Ca}$ were significantly $(P<0.05)$ higher than other treatments. The maximum number of flowers per raceme was recorded with $0.2 \mathrm{mg} \mathrm{g}^{-1}$ Ca treatment.

Number of pods per raceme: Pods per raceme increased with the increasing $\mathrm{Ca}$ level, but no significant difference $(P>0.05)$ was observed between $0.2 \mathrm{mg} \mathrm{g}^{-1} \mathrm{Ca}$ treatment and CK (Table 4). Likely, no significant difference $(P>0.05)$ was found for pods per raceme among $0.4,0.6$ and $0.8 \mathrm{mg} \mathrm{g}^{-1}$
$\mathrm{Ca}$ treatments, and all significantly $(P<0.05)$ higher than $\mathrm{CK}$ and $0.2 \mathrm{mg} \mathrm{g}^{-1} \mathrm{Ca}$ treatment.

Number of seeds per pod: The results showed that seeds per pod increased and then decreased with increasing $\mathrm{Ca}$ concentration, but no significant differences $(P>0.05)$ between $\mathrm{Ca}$ application and $\mathrm{CK}$ was found (Table 4). Among the $\mathrm{Ca}$ treatments, seeds per pod were highest in 0.4 $\mathrm{mg} \mathrm{g}^{-1}$ and significant differences $(P<0.05)$ was observed between $0.4 \mathrm{mg} \mathrm{g}^{-1}$ and $0.2 \mathrm{mg} \mathrm{g}^{-1}$ or $0.8 \mathrm{mg} \mathrm{g}^{-1}$ treatment.

\section{Effects of Ca Application on Seed Yield}

With the Ca level, increasing from 0.2 to $0.8 \mathrm{mg} \mathrm{g}^{-1}$, the seed yield increased primarily and then decreased, and 
for each $\mathrm{Ca}$ treatment, it was higher significantly $(P<0.05)$ than CK (Table 4). The highest seed yield of $585.41 \mathrm{~kg} \mathrm{ha}^{-1}$ was obtained in the $0.4 \mathrm{mg} \mathrm{g}^{-1}$ application treatment. There was significant difference between seed yield in 0.2 and 0.4 $\mathrm{mg} \mathrm{g}^{-1} \mathrm{Ca}$ treatment and higher significantly $(P<0.05)$ than 0.6 and $0.8 \mathrm{mg} \mathrm{g}^{-1}$.

\section{Correlation and Path-coefficient Analysis between Seed Yield and Yield Components}

Correlation between seed yield and yield components, flowers per raceme $\left(\mathrm{r}=0.56^{* *}\right)$ and pods per raceme $\left(\mathrm{r}=0.61^{* *}\right)$ were found significantly with seed yield over years and $\mathrm{Ca}$ treatments (Table 5). Correlation of raceme per square meter $(\mathrm{r}=0.01)$ and seeds per pod $(\mathrm{r}=0.09)$ was insignificantly with seed yield, respectively. There was also a significantly positive relationship between pods per raceme and flowers per raceme $\left(\mathrm{r}=0.67^{* *}\right)$. Significant correlation between raceme per square meter and pods per raceme $\left(\mathrm{r}=0.38^{* *}\right)$ or seeds per pod $\left(\mathrm{r}=0.41^{* *}\right)$ was found.

Path-coefficient (pc) analysis indicated non-significant direct effects of flowers per raceme and seeds per pod on alfalfa seed yield (Table 6). However, pods per raceme $\left(\mathrm{pc}=0.60^{* *}\right)$ and flowers per raceme $\left(\mathrm{pc}=0.40^{* *}\right)$ had significant and positive highest-direct effect on seed yield. Racemes per square meter had a negative and marginal direct effect on yield $(\mathrm{pc}=-0.22, P=0.1)$, but a positively indirect effect via pods per raceme resulted in the positive genetic correlation $(\mathrm{pc}=0.23)$ with seed yield (Table 6).

\section{Discussion}

The weather conditions showed significant variations during the consecutive 4 years. The favorable climate conditions in 2012 were beneficial to alfalfa seed production, nevertheless the unfavorable conditions during March-May accounted for the lower seed yield attained in 2010. Medeiros et al. (1995) found that too much rainfall during anthesis probably prevented insect fertilization resulting in losses of fertilized flowers and embryo abortion. Furthermore, alfalfa plants were lush and lodged easily with high rainfall (Karagić et al., 2009). Lodging reduced the number of viable flowers and stimulated regrowth from the crown or old branches, decreasing nutrient partitioning to the developing seed. Thus, the differences of climate conditions during cropping years could lead to development variations of perennial plants.

Differential response of seed yield components was found to foliar application of $\mathrm{Ca}$. Racemes per square meter and flowers per raceme decreased, but pods per raceme increased with $\mathrm{Ca}$ application concentration increasing from 0.2 to $0.8 \mathrm{mg} \mathrm{g}^{-1}$. Ca application also increased racemes per square meter, flowers per raceme decreased and pods per raceme compared with the CK. Taylor and Mirabel (1986) reported that racemes per square meter was a main seed yield component of alfalfa. However, Picchioni et al. (2002) delivered reverse conclusion that additional $\mathrm{Ca}$ treatment did not influence racemes per plant in Lupinus havardii after adding 4 concentrations of $\mathrm{Ca}(0,2.5,5.0,10.0 \mathrm{mM})$ to nutrient culture solution. Lamaire et al. (1995) reported that flower development was affected by $\mathrm{Ca}$ supply. The strongly positive correlation of alfalfa seed yield per plant with flowers per raceme was found by Mrázkov and Vacek (1981). The results in this experiment showed that 0.2 and $0.4 \mathrm{mg} \mathrm{g}^{-1} \mathrm{Ca}$ application could increase flowers per raceme in alfalfa. Kazemi (2013) reported that foliar application of salicylic acid and $\mathrm{Ca}$ had significant influence on vegetative and reproductive growth of strawberry (Fragaria $\times$ ananassa Duch.) and could increase the number of flowers. Similarly, results of Tang et al. (2007) showed that Ca supply through foliar spray could significantly increase the flower numbers of cyclamen (Cyclamen persicum L.). Abdoli et al. (2004) reported that pods per raceme was also an important component. Meena et al. (2007) concluded that $\mathrm{Ca}$ insufficiency resulted in groundnut pegs and pods to abort and reduced yield. Because of poor liquidity from older

Table 5: Simple correlation coefficients between seed yield and yield components in alfalfa

\begin{tabular}{lllll}
\hline Characters & Racemes per square meter & Flowers per raceme & Pods per raceme & Seeds per pod \\
\hline Racemes per square meter & 1 & 1 & & \\
Flowers per raceme & -0.179 & $0.673^{* *}$ & 1 & 0.207 \\
Pods per raceme & $0.376^{* *}$ & -0.122 & $0.613^{* *}$ & 1 \\
Seeds per pod & $0.409^{* *}$ & $0.557^{* *}$ & 0.096 \\
Seed yield & 0.011 & & & 1
\end{tabular}

Table 6: Path-coefficient analysis for seed yield and yield components in alfalfa and direct effects (underlined) and indirect effects are shown for racemes per square meter and pods per raceme

\begin{tabular}{llll}
\hline Characters & Racemes per square meter & Flowers per raceme & Pods per raceme \\
\hline Racemes per square meter & $\underline{-0.223}$ & -0.023 & 0.224 \\
Flowers per raceme & 0.040 & $\underline{0.126}$ & $0.401^{* *}$ \\
Pods per raceme & -0.084 & 0.085 & 0.032 \\
Seeds per pod & -0.091 & -0.015 & -0.010 \\
*** $P<0.01$ & & 0.016 & 0.123 \\
\hline
\end{tabular}

${ }^{* *} \mathrm{P}<0.01$ 
tissues to younger tissues, exogenous $\mathrm{Ca}$ must be requisite for the developing pod (Skelton and Shear, 1971). Thus, Ca supply contributed to pods development, which could increase the amount of mature pods per plant (Kabir et al., 2013). The present study findings are in agreement with the result of these experiments that $\mathrm{Ca}$ supply could significantly increase pods per raceme (Table 4). In addition, some researchers reported that seeds per pod was a steady relatively component in lots of crops (Idris, 2008; Zhang et al., 2008). Similarly, in this experiment, Ca application had not significant effect on seeds per pod.

Legumes were considered to have a higher requirement for $\mathrm{Ca}$ in their tissues than grasses. According to the results of this experiment, $\mathrm{Ca}$ application treatments could significantly $(P<0.05)$ increased seed yield by $20.8-$ $48.7 \%$ in alfalfa, but the highest seed yield was obtained for $0.4 \mathrm{mg} \mathrm{g}^{-1} \mathrm{Ca}$ application. Arshadullah et al. (2013) found that grain yield in wheat would be improved by $43 \%$ through application of $150 \mathrm{~kg} \mathrm{ha}^{-1} \mathrm{Ca}$ sulfate. Slack and Morrill (1972) pointed out that $\mathrm{Ca}$ was the most vital element in growth and development of peanut seeds and main limiting of the peanut production. Also $\mathrm{Ca}$ element was required by peanut plant from the time when pegs began to appear, fruit formation, until the pods were mature (Walker, 1975). Christos (2009) reported that Ca application could increase the chlorophyll concentration of plant. In addition, Ca supply could promote leaf photosynthetic rate (Yang et al., 2012). Thus, Ca application contributed to more synthesis of photosynthetic product and increased seed yield. Furthermore, Mahmood et al. (2009) reported that $\mathrm{Ca}$ supply could promote plant absorb nitrogen and increased nitrogen use efficiency, which contributed to the enhancement of seed yield. Thus, Ca supply could promote crop development. According to findings of present study, $\mathrm{Ca}$ application contributed to reproductive growth of alfalfa and improved the amount of vegetative organs including racemes per square meter, flowers per raceme and pods per raceme.

Alfalfa seed yield was reported to be significantly correlated with yield components (Ilić and Đukić, 2006). Bodzon (2004) reported that flowers per raceme had a significant relation with seed yield. Du et al. (2009) and Abadouz et al. (2010) pointed out positive correlation between pods per raceme and seed yield. These findings agreed with the result of this experiment. Ilić and Đukić (2006) found that the correlation between seeds per pod and seed yield was not meaningful.

Path-coefficient analysis was used to determine the amount of direct and indirect effect of the causal components on the effect components. Among yield components, pods per raceme had the significantly and positively highest-direct effect $\left(\mathrm{pc}=0.60^{* *}\right)$ on seed yield (Table 6), as reported by Suleyman (2006) in alfalfa and Murat and Çiftci (2007) in rape. These findings implied that pods per raceme could serve as a selection index to enhance seed yield in alfalfa.

\section{Conclusion}

Results of this experiment suggests that $\mathrm{Ca}$ application could make profitable seed harvest, and application of 0.4 $\mathrm{mg} \mathrm{g}^{-1} \mathrm{Ca}$ resulted in the best growth and seed yield of alfalfa. Among seed yield components, pods per raceme showed highest sensitivity to $\mathrm{Ca}$ application, which implied pods per raceme was a key yield component in alfalfa when supplying Ca.

\section{Acknowledgments}

This research was financially supported by National Key Technologies R\&D Program of the $12^{\text {th }}$ Five-Year Plan (2011BAD17B01-02).

\section{References}

Abadouz, G., H.G. Abdollah, A.R. Abdol and B. Adela, 2010. Effect of row spacing and seeding rate on yield component and seed yield of alfalfa (Medicago sativa L.). Not. Sci. Biol., 2: 74-80

Abdoli, P., S.A. Siadat, G. Fathi and E. Farshadfar, 2004. Effect of planting date on yield criteria of some canola genotypes in Kermanshah. Sci. J. Agric., 27: 105-117

Arshadullah, M., S.I. Hyder, A. Ali and I.A. Mahmood, 2013. Cumulative effect of sulfur and $\mathrm{Ca}$ on wheat growth and yield under saline-sodic soils. Pak. J. Agric. Res., 26: 46-53

Barnes, D.K. and C.C. Sheaffer, 1995. Alfalfa. In: Forages: An Introduction to Grassland Agriculture, Vol. I, pp: 205-216. Barnes, R.F., D.A. Miller and C.J. Nelson (eds.). Iowa State University Press, Ames, Iowa, USA

Bodzon, Z., 2004. Correlations and heritability of the characters determining the seed yield of the long-raceme alfalfa (Medicago sativa L.). J. Appl. Genet., 45: 49-60

Bolanos-Aguilar, E.D., C. Huyghe, B. Julier and C. Ecalle, 2000. Genetic variation for seed yield and its components in alfalfa (Medicago sativa L.). Agronomy, 20: 335-345

Christos, D., 2009. Foliar application of $\mathrm{Ca}$ and magnesium improves growth, yield, and essential oil yield of oregano (Origanum vulgaressp. hirtum). Ind. Crop Prod., 29: 599-608

Du, W.H., X.H. Tian, Z.Z. Cao and A. Humphries, 2009. Effects of micronutrients on seed yield and yield components of alfalfa. $J$. Plant Nutr., 32: 809-820

Falcinelli, M., 1999. Temperate forage seed production: conventional and potential breeding strategies. J. New Seeds, 1: 37-66

Gashti, A.H., M.N.S. Vishekaei and M.H. Hosseinzadeh, 2012. Effect of potassium and calcium application on yield, yield components and qualitative characteristics of peanut (Arachis hypogaea L.) in Guilan province, Iran. World Appl. Sci. J., 16: 540-546

Idris, A.L.Y., 2008. Effect of seed size and plant spacing on yield and yield components of faba bean (Vicia faba L.). Res. J. Agric. Biol. Sci., 4: 146-148

Ilić, O. and D. Đukić, 2006. Correlations among alfalfa yield components. Genetika, 38: 251-258

Jiang, Y.B., J.H. Li, L.Y. Fang and C.Z. Wang, 2008. Effect of calcium on drought resisting of alfalfa seedlings. Chin. J. Grassl., 1: 117-120

Kabir, R., S. Yeasmin, Mominul, A.K.M. Islam and M.A.R. Sarkar, 2013. Effect of phosphorus, calcium and boron on the growth and yield of groundnut (Arachis hypogea L.). Int. J. Bio-Sci. Bio-Technol., 5: 5159

Karagić, D., S. Katic, D. Milic, S. Vasiljević and B. Milonević, 2009. Alfalfa seed production in semi-humid climate of the southeast Europe. Inst. Field Vegetable Crop, 2: 38-42

Kazemi, M., 2013. Foliar application of salicylic acid and Ca on yield, yield component and chemical properties of strawberry. Bull. Environ. Pharmacol. Life Sci., 2: 19-23 
Kudla, J., O. Batistic and K. Hashimoto, 2010. Ca signals: the lead currency of plant information processing. Plant Cell, 22: 541-563

Lamaire, F., G. Sintes, P. Morel, F. Tognoui, T. Namili and A. Nukaya, 1995. Mineral needs of Begonia elatior during the growing period and the flowering time. Acta Hortic., 396: 219-226

Liu, B., W.H. Zhou, S.L. Shi and P. Zhao, 2011. Ameliorating effects of exogenous $\mathrm{Ca}^{2+}$ and salicylic acid on alfalfa seedlings under salt stress. Chin. J. Grassl., 33: 42-47

Mahmood, I.A., M. Salim, A. Ali, M. Arshadullah, B. Zaman and A. Mir, 2009. Impact of $\mathrm{Ca}$ sulphate and $\mathrm{Ca}$ carbide on nitrogen use efficiency of wheat in normal and saline sodic soils. Soil Environ., 28: $29-37$

Marschner, H., 1995. Magnesium, Mineral Nutrition of Higher Plants, $2^{\text {nd }}$ edition, pp: 277-285. Academic Press, London, UK

Medeiros, R.B., A.V.A. Jacques and C. Nabinger, 1995. Alfalfa (Medicago sativa L.) seed production under different row spacing and plant population in the seeding year. In: Proceedings of the Third International Hervage Seed Conference, Halle (Sale), Germany, pp: 331-335. June 18-23

Meena, S., M. Malarkodi and P. Senthilvalavan, 2007. Secondary and micronutrients for groundnut, a review. Agric. Rev., 28: 295-300

Mrázkov, V. and V. Vacek, 1981. An evaluation of alfalfa cultivars from the viewpoint of seed production. Rost. Vyr. R., 27: 857-863

Murat, T. and V. Çiftci, 2007. Relationships between yield and some yield components in rape seed (Brassica napus ssp. oleifera L.) cultivars by using correlation. Pak. J. Bot., 39: 81-84

N̦arinov and Kljuj, 1990. Ljucerna, 2. Izdanie, pererabotano I dopolnenoe. Uronaj, Kiev, 238

Picchioni, G.A., M. Valenzuela-Vazquez and L.W. Murray, 2002. Ca and 1methylcyclopropene delay desiccation of Lupinush avardii cut racemes. Hort. Sci., 37: 122-125

Reddy, A.S.N., 2001. Ca: silver bullet in signaling. Plant Sci., 160: 381-404

Rincker, C.M., V.L. Marble, D.E. Brown and C.A. Johansen, 1988. Seed production practices. In: Alfalfa Science and Technology, pp: 9851012. Hanson, C.H. (ed.). Agronomy 29. ASA, CSSA, SSSA Publishers, Madison, Wisconsin, USA
Skelton, B.J. and G.M. Shear, 1971. Ca translocation in the peanut (Arachis hypogaea L.). Agron. J., 63: 409-412

Slack, T.E. and L.G. Morrill, 1972. A comparison of a large-seeded (NC2) and a small-seeded (Starr) peanut (Arachis hypogaea L.) cultivar as affected by levels of $\mathrm{Ca}$ added to the fruit zone. Soil Sci. Soc. Amer. J., 36: 87-90

Suleyman, S., 2006. Using path analysis to determine lucerne (Medicago sativa L.) seed yield and its components. New Zeal. J. Agric. Res., 49: $107-115$

Tang, S., W. Shi, H. Wang and A. Luo, 2007. Effect of Ca on cyclamen pedicel elongation. J. Plant Nutr. Soil Sci., 170: 664-668

Taylor, A.G. and V.L. Mirabel, 1986. Lucerne irrigation and soil water use during bloom and seed set on a red-brown earth in S. E. Australia. Aust. J. Exp. Agric., 26: 577-581

Walker, M.E., 1975. Ca requirements for peanuts. Commun. Soil Sci. Plant Anal., 6: 299-313

Wang, J.Y., X.M. Zhang and G.L. Li, 2004. Effects of $\mathrm{Ca}^{2+}$ on soybean growth and yield. Chin. J. Oil Crop Sci., 26: 60-62

$\mathrm{Xu}, \mathrm{C}$., X. Li and L. Zhang, 2013. The effect of Ca chloride on growth, photosynthesis, and antioxidant responses of Zoysia japonica under drought conditions. Plos One, 8: e68214

Yang, L.J., H. Qua, Y.L. Zhang and F.S. Li, 2012. Effects of partial rootzone irrigation on physiology, fruit yield and quality and water use efficiency of tomato under different Ca levels. Agric. Water Manage., 104: 89-94

You, J.H., J.M. Lu and W.J. Yang, 2003. Effects of Ca on cold tolerance and related physiological indices of alfalfa seedlings. Acta Pratacul. Sci., 12: $30-33$

Zhang, T.J., X.G. Wang, J.G. Han, Y.W. Wang, P.S. Mao and M. Majerus, 2008. Effects of between-row and within-row spacing on alfalfa seed yields. Crop Sci., 48: 794-803

(Received 19 June 2015; Accepted 20 November 2015) 